\title{
KOMUNIKASI POLITIK PARTAI KEADILAN SEJAHTERA (PKS) DALAM KETERBUKAAN IDEOLOGI
}

\author{
Erfina Nurussa'adah ${ }^{1}$, Suwandi Sumartias ${ }^{2}$ \\ ${ }^{1}$ Universitas Islam Negeri Sunan Kalijaga Yogyakarta \\ ${ }^{2}$ Universitas Padjadjaran
}

\begin{abstract}
ABSTRAK
Penelitian ini bertujuan untuk menganalisis komunikasi politik Partai Keadilan Sejahtera (PKS) dalam keterbukaan ideologi yang dilakukan DPW PKS Jawa Barat. Untuk menjawab permasalahan tersebut,dilakukan analisis terhadap pokok pertanyaan penelitian, yaitu: komunikasi politik DPW PKS Jawa Barat dalam keterbukaan ideologi. Pendekatan yang digunakan dalam penelitian ini adalah kualitatif dengan studi etnografi komunikasi. Subjek penelitian adalah DPW PKS Jawa Barat. Dalam penelitian ini narasumber wawancara dibagi menjadi dua yaitu internal dan eksternal, yang dipilih secara purposive sampling (sampel bertujuan) dengan jumlah narasumber internal 5 orang dan narasumber eksternal 4 orang. Data penelitian diperoleh melalui wawancara mendalam, observasi, dokumentasi, studi pustaka. Adapun teknis analisis data dengan mereduksi data, mengumpulkan data, menyajikan data, menarik kesimpulan, dan evaluasi. Hasil penelitian menunjukkan bahwa, komunikasi politik yang berlangsung dalam keterbukaan ideologi DPW PKS Jawa Barat melibatkan komunikator-komunikator politik dari dalam dan luar PKS. Selain itu, komunikasi juga melibatkan kader, simpatisan, masyarakat Jawa Barat serta tamu undangan sebagai komunikannya. Komunikasi politik yang terjadi dalam keterbukaan ideologi melalui pesan verbal dan nonverbal yang disampaikan dalam beberapa kegiatan DPW PKS Jawa Barat seperti; Muswil, Rakerwil dan Rakorwil. Komunikasi politik dalam keterbukaan ideologi DPW PKS Jawa Barat terjadi melalui pola komunikasi organisasi, dengan penyampaian pesan berupa pidato serta arahan. Dalam komunikasi politik, kegiatan tersebut merupakan bentuk dari retorika, propaganda, public relations, kampanye politik, serta lobi politik..
\end{abstract}

Kata-kata Kunci: Komunikasi politik, keterbukaan ideologi, pola komunikasi, DPW PKS, Jawa Barat

\section{PARTAI KEADILAN SEJAHTERA (PKS)'S POLITICAL COMMUNICATION TOWARDS DISCLOSURE OF IDEOLOGY}

\begin{abstract}
This study aims to analyze the political communication of Prosperous Justice Party (PKS) towards an open ideology. To address these problems, author should answer the research question, namely: political communication of DPW PKS West Java in the ideology of openness. This study used a qualitative method with communication ethnographic design. Research subject was DPW PKS West Java. In this study, informant divided into two groups, internal and external. Informant were selected by purposive sampling (samples intended). Internal speaker consist of 5 person and external speakers consist of 4 person. Data were obtained through interviews, observation, documentation, literature. Data analysis comprehend of reduction, collecting data, presenting data, draw conclusions, and evaluation. The results showed that, political communication that takes place in the ideology of openness DPW PKS West Java involve political communicators from inseide and outside PKS. Moreover, PKS involves cadres, sympathizers, people of West Java as well as invited guests as communicators. Political communication occurs in verbal and nonverbal messages which are delivered in several activities such as West Java branch of MCC; Muswil, Rakerwil and Rakorwil. The political communication occur through organizational communication patterns, where the message delivered through speeches and directives. In political communication, such activities are a form of rhetoric, propaganda, public relations, political campaigns and political lobbying.
\end{abstract}

Keywords: Political communication, public ideology, communication pattern, DPW PKS, West Java

Korespondensi: Erfina Nurussa'adah, M.I.Kom. Universitas Islam Negeri Sunan Kalijaga Yogyakarta. J1. Laksda Adisucipto, Caturtunggal, Kec. Depok, Kabupaten Sleman, Daerah Istimewa Yogyakarta 55281. Email: nurussaadaherfina@gmail.comgmail.com 


\section{PENDAHULUAN}

Kehidupan partai politik di Indonesia cenderung mengedepankan kepentingan politik praktis dan mengesampingkan nilai ideologi. Pergeseran nilai ideologi dalam partai politik bukan sesuatu yang baru. Demi kepentingan kekuasaan, partai politik akan berlomba-lomba membuka diri untuk dapat mewadahi semua basis pemilih. Kondisi ini menjadikan ideologi partai tidak lagi menjadi unsur utama dalam pembuatan keputusan internal partai, selain itu ideologi tidak lagi menjadi tolak ukur dalam menyusun kebijakan. Fenomena menarik ketika partai kader atau partai doktriner semakin membuka diri pada partai-partai berideologi sekuler ataupun nasionalis. Sehingga partai tersebut bertransformasi menjadi partai yang pragmatis.

Keterbukaan ideologi bagi partai politik menjadi salah satu pilihan untuk memperoleh dan mempertahankan kekuasaan. Salah satunya Partai Keadilan Sejahtera (PKS). Sejak menggelar Musyawarah Kerja Nasional (Mukernas) di Bali, tanggal 1-3 Februari 2008, PKS menegaskan eksistensi dan peran PKS yang membuka diri untuk berkomunikasi dan berkerjasama dengan berbagai unsur kekuatan bangsa (Kompas, 2008). Situasi ini ditegaskan kembali pada hasil Musyawarah Nasional (Munas) ke-2 pada tanggal, 16-20 Juni 2010, di Jakarta yang menjadikan PKS sebagai partai terbuka (inklusif).

Lahirnya Partai Keadilan Sejahtera (PKS) tidak terlepas dari peran Partai Keadilan (PK). Perubahan PK menjadi PKS dikarenakan pada saat pemilu tahun 1999, PK tidak mampu memenuhi ambang batas parlemen sebesar 2\%. Kondisi tersebut mengharuskan PK berganti nama serta lambang utuk dapat mengikuti pemilu tahun 2004. Selanjutnya PK berganti menjadi Partai Keadilan Sejahtera (PKS) yang dipakai secara resmi sejak tanggal 2 Juli 2003 (Setya, 2009).

PKS menjadi salah satu partai Islam yang diperhitungkan sejak kemunculannya karena berhasil menjadi partai tengah dan mampu bersaing bahkan mengungguli partai Islam lainnya. PKS pun mampu bertahan di tengah gempuran partai nasioanalis seperti demokrat pada pemilu tahun 2009 dan mampu mendudukkan anggotanya di parlemen melebihi partai Islam lainnya. Performa PKS pun terlihat di pilkada di beberapa daerah di Indonesia seperti; pilkada DKI Jakarta, pilkada Kalimantan Selatan, pilkada Sumatera Utara dan pilkada Jawa Barat. Dalam pilkada Jawa Barat tersebut, PKS mampu mendominasi suara selama dua kali periode pemilihan kepala daerah. Kondisi tersebut membuktikan bahwa elektabilitas serta eksistensi PKS tidak tergerus oleh kasus-kasus seperti korupsi, kisruh internal dan eksternal partai, yang melibatkan elite partai PKS serta pilihan PKS untuk lebih terbuka pada semua golongan dan agama.

Partai PKS pada awalnya dicitrakan sebagai partai eksklusif dengan mengusung Gerakan Tarbiyah. Gerakan Tarbiyah merupakan gerakan dengan konsep Tarbiyah Islamiyah yaitu penyiapan manusia yang saleh agar tercipta keseimbangan dalam potensi, tujuan, ucapan, dan tindakan dengan tujuan menciptakan kondisi yang kondusif bagi manusia untuk hidup secara lurus, baik dengan ridha dan pahala Allah SWT (Taufik, 2009: 34).

Keterbukaan ideologi PKS ditunjukkan dengan perubahan semboyan partai menjadi "PKS untuk semua" pada pemilu tahun 2009 serta perubahan visi dan misi serta AD/ART partai. Orientasi yang ditonjolkan dari pilihan terbuka ini adalah mencoba melegal formalkan (sesuai dengan peraturan perundang-undangan atau hukum peraturan yang sah) keanggotaan kalangan non-Muslim. Situasi ini didasarkan pada pertimbangan akan signifikansi dukungan sebagian kalangan non-Muslim di wilayahwilayah yang mayoritas penduduknya nonMuslim, seperti Papua, dan Nusa Tenggara Timur. Selain itu indikator keterbukaan PKS dapat kita lihat dari kebijakan-kebijakan yang ditelurkan oleh elite-elite PKS dalam skala nasional maupun skala lokal seperti; melegalformalkan keanggotaan kalangan nonMuslim, serta mendekati basis massa tradisional Islam.

Berkaitan dengan keterbukaan PKS, Humas DPW PKS Jawa Barat, menjelaskan bahwa keterbukaan itu adalah bukti bahwa PKS yang sekarang lebih moderat atau dikenal dengan al wasattiyah 'moderatisme' yang menjadi prinsip fikroh atau gagasan PKS. Keterbukaan yang dipahami di sini adalah sikap toleransi, proporsional, moderat serta sikap bekerja sama dengan siapapun.

Teori interaksi simbolik George Herbert Mead (dalam Ritzer, 2012: 603-623) 
mengemukakan beberapa konsep dari teori: (1) Tindakan. Mead menganggap tindakan sebagai “unit paling primitif” di dalam teorinya. Dalam menganalisis tindakan pendekatan yang digunakan Mead adalah behavioris yang berfokus pada stimulus dan respon, (2) Gerak Isyarat (gestur). Gerak isyarat diartikan bahwa tindakan suatu individu tanpa berpikir panjang dan secara otomatis mendatangkan suatu reaksi oleh individu lain, (3) Simbol-simbol signifikan. Simbol signifikan memungkinkan interaksi simbolik. Yaitu orang dapat berinteraksi satu sama lain bukan hanya melalui gerak insyarat tetapi juga melalui simbol signifikan. Kemampuan tersebut membuat perbedaan dan memungkinkan pola-pola interaksi dan bentuk-bentuk organisasi sosial yang jauh lebih kompleks dari pada yang dimungkinkan melalui gerak insyarat saja. Simbol signifikan jelas memainkan suatu peran sentral di dalam pemikiran Mead, (4) Pikiran (mind). Kemampuan individu membangkitkan di dalam dirinya bukan hanya respon tunggal dari orang lain tetapi respon komunitas secara keseluruhan. (5) Diri (self). Pada dasarnya kemampuan untuk menjadikan diri sendiri sebagai objek. Diri adalah kemampuan khas untuk menjadi subjek dan objek. Menurut konsep utama Mead, diri mengendalikan suatu proses sosial komunikasi di antara manusia, dan (6) Masyarakat (society). Istilah masyarakat menurut Mead adalah proses sosial yang terus menerus yang mendahului pikiran maupun diri. Yang artinya bahwa masyarakat ada sebelum individu dan proses mental atau proses berpikir muncul dalam masyarakat. Karena menurut Mead masyarakat sebagai pola interaksi dan intuisi sosial.

Secara umum Miriam Budiharjo (dalam Arifin, 2011: 30) menjelaskan bahwa partai politik merupakan suatu kelompok yang terorganisasi, anggota-anggotanya memiliki orientasinilai-nilaiyang samauntukmemperoleh kekuasaan dan merebut kedudukan politik agar dapat melaksanakan programnya karena kekuasaan dan kedudukan politik diperoleh secara konstitusional untuk mempengaruhi dan melaksanakan kebijakan umum (public policy).

Dari hal tersebut menjadikan partai politik memiliki basis sosiologis yaitu cita-cita dan kepentingan yang diarahkan untuk memperoleh kekuasaan. Sehingga partai politik mampu membangun citra dirinya dengan pendukungnya, yang menjadikan pengelompokan partai politik secara basis sosiologis yaitu (1) partai massa, (2) partai kader, (3) partai lindungan, dan (4) partai ideologi (Arifin, 2011: 30).

Sebagai partai politik, PKS tentu melakukan komunikasi politik dalam setiap aktivitas politik yang dilakukan, baik dalam segi pemikiran politik, pembicaraan politik dan tindakan politik. Aktivitas politik yang dilakukan PKS tidak terlepas dari keterbukaan ideologi partai yang mereka usung saat ini. Keterbukaan ideologi tersebut akan membawa citra baru bagi PKS, yang awalnya eksklusif menjadi inklusif.

Kebebasan dalam berkomunikasi yang mewarnai kehidupan politik, berdampak terhadap tuntutan demokratisasi bernegara yang faktual melalui pemilihan umum yang berkeadilan dan menghasilkan anggota legislatif yang berpihak kepada rakyat (Susanto, 2013). Komunikasi politik dalam suatu partai politik merupakan penghubung segala informasi atau pesan baik verbal maupun nonverbal terhadap masyarakat luas dan anggota partai politik itu sendiri. DPW PKS Jawa Barat menggunakan komunikasi politik untuk menyampaikan keterbukaan ideologi politik mereka. Salah satunya dengan penyampaian beberapa slogan partai seperti "bersih dan peduli", "partai kita semua", "PKS untuk semua" "berkhidmat untuk rakyat" di semua level.

Merujuk dari uraian di atas dapat di rumuskan bahwa komunikasi politik adalah pembicaraan yang bertujuan memengaruhi dalam kehidupan bernegara (Arifin, 2011: 8-9). Perpaduan komunikasi dan politik membuat komunikasi keluar dari "tempurung" proses yang bersifat mekanistis yang disebut "komunikasi mikro". Sedangkan komunikasi politik yang mengaitkan komunikasi dengan kekuasaan, ideologi, demokrasi dan sebagainya, telah membawa komunikasi ke arah lintas disiplin atau multi disipliner yang disebut "komunikasi makro". Komunikasi politik juga bersifat "tidak bebas nilai" yang sangat terkait dengan faktor sejarah dan kultural, termasuk ideologi, sistem politik, sistem sosial dan sistem ekonomi suatu negara-bangsa.

Keterbukaan terhadap partai yang memiliki platform yang berbeda menandakan bahwa jarak ideologi di antara partai-partai politik saat ini semakin menyatu dan tidak ada sekat di antara partai yang memiliki ideologi yang berbeda. Giovanni Sartori menyebut fenomena ini sebagai 
kecenderungan sentripetal dalam partai politik (Surbakti, 2010: 128). Menurut Sartori, dalam demokrasi yang sudah terinstitusionalisasi secara baik, ideologi partai akan mengarah ke tengah dan membuat sekat ideologi antar partai semakin tidak jelas. Dengan kata lain partaipartai politik akan semakin pragmatis dalam upaya mendapatkan kekuasaan (Surbakti, 2010: 128). Walau demikian terdapat hasil penelitian yang menyebutkan bahwa: perhatian masyarakat lebih banyak ditujukan pada kasus politik yang melibatkan public figure yang diberitakan dan diisukan (Wibowo \& Mirawati, 2013). Artinya pemahaman masyarakat belum mengarah pada faktor ideologi partai politik.

Seiring dengan perkembangannya, perlu kita telaah lebih lanjut di mana PKS sebagai partai baru yang berbeda dari partai politik kebanyakan, dan terlebih lagi dapat diketahui bahwa PKS berasal dari komunitas Muslim baru di Indonesia. Dalam perkembangan kepartaian saat ini, ada kesan ideologi yang diusungnya semakin bergerak ke tengah. PKS memilih untuk menjadi partai politik yang terbuka atau bisa dimaknai bahwa Partai Keadilan Sejahtera (PKS) saat ini memilih untuk menjadi partai yang plural, menerima perbedaan dan keberagaman.

Komunikasi politik PKS tidak terlepas dari kegiatan retorika, agitasi politik, propaganda, Public Relation (PR) Politic, kampanye politik, lobi politik, serta lawat media massa dalam mengusung keterbukaan ideologinya. Penyampainan perubahan visi, misi, AD/ART, semboyan partai, paltform kebijakan partai, khittah perjuangn serta tujuan politik lainnya yang mendukung keterbukaan ideologi politik PKS dilakukan melalui beberapa bentuk komunikasi politik tersebut.

Sebagaimana telah dipaparkan di atas, keterbukaan ideologi partai politik akan mempengaruhi strategi komunikasi politik partai baik itu bagi partai yang berkuasa maupun saat pemilu. Kondisi ini juga terjadi pada PKS. Keputusan untuk membuka diri pada semua golongan akan mempengaruhi komunikasi politik sebuah partai politik, baik internal maupun eksternal. Keterbukaan ideologi dipilih dengan pertimbangan bahwa dalam kehidupan politik di Indonesia, fenomena keterbukaan ideologi bukan saja membuat masyarakat kesulitan melihat perbedaan partai kiri dan partai kanan. Lebih penting dari itu adalah semakin jauh jarak partai itu sendiri dari basis historis pendirinya, dan perlu dipertanyakan lagi akan kosistensi ideologi partai yang menjadi nafas perjuangan partai. Pertimbangan lain adalah kurangnya kepercayaan masyarakat terhadap partai-partai yang membawa ideologi sebagai asas perjuangan, seperti misalnya partai berbasis Islam. Kondisi tersebut yang kemudian menyebabkan berkurangnya perolehan suara beberapa partai Islam pada pemilu belakangan. Dengan demikian keterbukaan ideologi partai politik mempunyai kontribusi terhadap perilaku masyarakat secara tidak langsung.

Pemahaman tersebut penting karena dalam sebuah keterbukaan ideologi yang terjadi di dalam partai politik terdapat komunikasi yang melingkupinya. Komunikasi tersebut dipertukarkan melalui cara berbicara, pola komunikasi yang akrab dari para anggota, komunitas bahasa, situasi bahasa, peristiwa bahasa, tindak bahasa, kegunaan tindak bahasa, aturan berbicara, serta fungsi bahasa. Sebuah aktivitas politik sangat dipengaruhi oleh bagaimana komunikasi personal, komunikasi intra personal, komunikasi organisai dan komunikasi massa dalam kontes komunikasi politik. Situasi tersebut berimplikasi pada hasil aktivitas politik. Dalam penelitian ini komunikasi politik yang berlangsung dapat memberikan ruang bagi pertukaran informasi serta interaksi yang tidak dapat dibatasi organisasi partai PKS dari keadaan lama yang eksklusif menjadi inklusif khususnya di Jawa Barat.

Maksud dari penelitian ini adalah untuk mengidentifikasi dan mengeksplorasi komunikasi politik dalam keterbukaan ideologi DPW PKS Jawa Barat. Tujuan dari penelitian ini adalah untuk mengetahui komunikasi politik DPW PKS Jawa Barat dalam keterbukaan ideologinya.

Hasil penelitian ini diharapkan dapat memberikan manfaat teoritis dan manfaat praktis, yakni memberikan kontribusi terhadap pemahaman tentang teori interaksi simbolik. Selain itu penelitian ini diharapkan dapat memperkaya kajian dalam bidang komunikasi terkait komunikasi politik khususnya. Kemudian penelitian ini diharapkan dapat menjadi kerangka acuan partai politik dalam mengkomunikasikan keterbukaan ideologinya baik secara aplikatif atau praktik melalui komunikasi antar pribadi, komunikasi organisasi 
atau kelompok, serta komuniksi massa dan lainlain dalam lingkup komunikasi politik serta sebagai bahan pertimbangan serta evaluasi bagi partai PKS khususnya dan partai Islam pada umumnya dalam membuat kebijakan.

\section{METODE PENELITIAN}

Pendekatan yang digunakan dalam penelitian ini adalah pendekatan kualitatif, karena penelitian ini berusaha untuk memahami komunikasi politik DPW PKS Jawa Barat dalam keterbukaan ideologinya. Sebagaimana yang dikatakan (Creswell, 1998: 15), bahwa penelitian kualitatif dilakukan dalam konteks natural, dan dalam proses penyelidikan untuk mengeksplorasi permasalahan manusia atau sosial.

Penelitian ini menggunakan paradigma konstruktivis untuk dapat menjelaskan dan menafsirkan keterbukaan ideologi PKS yang akan disampaikan melalui pertanyaan penelitan dan akan dijadikan data untuk tujuan akhir sebuah bentuk komunikasi politik. Metode penelitian yang digunakan adalah etnografi komunikasi, yakni sebuah metode untuk memaparkan pola-pola atau cara-cara berinteraksi atau berkomunikasi dalam setiap peristiwa komunikasi dalam organisasi politik atau partai politik. Interaksi ini terjadi di DPW PKS Jawa Barat, yang berfokus pada komunikasi politik dalam keterbukaan ideologi, kegiatan komunikasi politik dalam keterbukaan ideologi serta nilai dari keterbukaan ideologi. Metode etnografi komunikasi dianggap tepat karena penelitian etnografi adalah salah satu desain penelitian kualitatif di mana peneliti menjelaskan dan menafsirkan pola bersama yang meliputi nilai (value), perilaku(behaviors), keyakinan (belief), dan bahasa (languange) dari suatu kelompok budaya (Creswell, 1998: 90).

Etnografi komunikasi merupakan pendekatan dalam sosiolinguistik bahasa yaitu melihat penggunaan bahasa secara umum dihubungkan dengan nilai-nilai sosial dan kultural. Dengan kata lain, etnografi komunikasi menggabungkan sosiologi (analisis interaksional dan identitas peran) dengan antropologi (kebiasaan penggunaan bahasa dan filosofi yang melatarbelakanginya) dalam konteks komunikasi, atau ketika bahasa itu dipertukarkan (Kuswarno, 2008: 13). Selain itu Hymes (1971: 4 dalam Alwasilah, 2003: 61) mengatakan bahwa:

".... it is not linguistics, but ethnog-raphy, not language, but communication, which must provide the frame of reference within which the place of language in culture and society is to be assessed". (ini bukan linguistik, tetapi etnografi, bukan bahasa, tetapi komunikasi, yang harus melengkapi kerangka pikir secara mendalam tempat bahasa dalam kebudayaan dan masyarakat ditetapkan).

Subjek dalam penelitian ini adalah Dewan Pimpinan Wilayah (DPW) PKS Jawa Barat yang diwakili oleh komunikator intenal dan eksternal, komunikan internal dan eksternal serta masyarakat Jawa Barat dalam kegiatan kegiatan Muswil, Rakerwil dan Rakorwil serta informan internal PKS dan eksternal PKS. Subjek dipilih secara purposive sampling (sampel bertujuan), karena pemilihan satu kasus atau satu individu lazimnya didasari pertimbangan bahwa kasus atau individu tersebut dianggap khas (typical) sebagai subjek penelitian. Hal ini sejalan dengan pemikiran Creswell (dalam Kuswarno, 2008: 62) menjelaskan akses pertama etnografer di lapangan adalah "gatekeeper", yaitu seseorang yang merupakan anggota atau bagian dari kegiatan komunikasi politik PKS dalam keterbukaan ideologi.

Objek penelitian ini adalah fenomena yang terkait dengan komunikasi politik PKS dalam keterbukaan ideologi meliputi komunikasi politik dalam keterbukaan ideologi (proses komunikasi politik melalui kegiatan Muswil, Rakerwil dan Rakorwil). Kegiatan komunikasi politik dalam keterbukaan ideologi (pola komunikasi politik dalam keterbukaan ideologi). Nilai dibalik keterbukaan ideologi (pandangan mengenai keterbukaan ideologi). Objek situasi sosial yang diobservasi meliputi tempat aktivitas kegiatan komunikasi politik seperti kegiatan Muswil, Rakerwil dan Rakorwil baik di dalam ruangan maupun di luar ruangan yang terkait dan disepakati.

Objek dalam penelitian etnografi komunikasi menurut Kuswarno (2008: 38-46) yaitu masyarakat tutur (speech community), aktivitas komunikasi, komponen komunikasi, kompetensi komunikasi, serta varietas bahasa. Berikut unit-unit aktivitas komunikasi yang dikemukakan Hymes dalam Kuswarno, 2008: 41): (a) Situasi komunikatif atau konteks terjadinya komunikasi, (b) Peristiwa komunikatif atau keseluruhan perangkat 
komponen yang utuh yang dimulai dengan tujuan umum komunikasi, topik umum yang sama, dan melibatkan partisipan yang secara umum menggunakan varietas bahasa yang sama, mempertahankan tone yang sama, kaidahkaidah yang sama untuk interaksi, dalam setting yang sama, dan (c) Tindakan komunikatif, yaitu fungsi interaksi tunggal, seperti penyataan, permohonan, perintah, ataupun perilaku non verbal.

Teknis pengumpulan data yang dilakukan adalah observasi partisipan, wawancara mendalam, dan telaah dokumen. Analisis data dilakukan dengan meringkas data, memilih, menerjemahkan dan mengorganisasikan data. Teknik pemeriksaan keabsahan data dilakukan dengan cara perpanjangan keikutsertaan, ketekunan pengamatan, triangulasi, analisis kasus negatif, kecakupan referensi, pengecekan anggota, uraian rinci, dan auditing. Penelitian dilakukan di Kota Bandung sejak bulan Juli 2015 dan selesai pada bulan Februari 2016.

\section{HASIL DAN PEMBAHASAN}

Hasil penelitian ini mencakup satu pokok permasalahan yaitu komunikasi politik DPW PKS Jawa Barat dalam keterbukaan ideologi. Pokok permasalahan tersebut akan diuraikan secara runtut beserta modelnya.

Komunikasi dalam suatu organisasi selalu merupakan komunikasi satu arah maupun dua arah, demi kepentingan semua pihak. Dalam berkomunikasi kita menciptakan persamaan pengertian, ide, pemikiran, dan sikap tingkah laku kita terhadap orang lain. Komunikasi politik merupakan bagian dalam komunikasi di organisasi politik, kodisi ini dapat dilihat dari pola komunikasi dalam komunikasi politik yang juga terdapat dalam komunikasi organisasi, seperti komunikasi internal, dan eksternal, komunikai vertikal, horizontal, komunikasi satu arah dan dua arah serta komunikasi verbal, dan nonverbal.

Selain itu, berdasarkan unsur-unsur komunikasi pada umumnya, maka komunikasi politik pun terdiri dari beberapa unsur. Salah satu model komunikasi yang cukup simpel dan mewakili aspek-aspek dalam komunikasi adalah model yang dikemukakan oleh Harold Lasswell (1948) yang menggambarkan proses komunikasi dan fungsi-fungsi yang diembannya dalam masyarakat. Model komunikasi Lasswell berupa ungkapan verbal, yakni who says what in which channel to whom with what effect? Bila dijabarkan berdasarkan model tersebut, maka unsur-unsur komunikasi politik meliputi komunikator politik, pesan politik, media komunikasi politik, komunikan politik dan efek apa yang terjadi setelah komunikan menerima pesan politik dari komunikator politik (Mulyana dalam Permana, 2015).

Komunikasi politik yang berlangsung dalam keterbukaan ideologi DPW PKS Jawa Barat melibatkan komunikator-komunikator politik dari PKS dan dari luar PKS. Selain itu, komunikasi juga melibatkan kader, simpatisan, masyarakat Jawa Barat serta tamu undangan sebagai komunikannya. Komunikasi politik yang terjadi dalam keterbukaan ideologi melalui pesan verbal dan nonverbal yang disampaikan dalam beberapa kegiatan DPW PKS Jawa Barat seperti; Muswil, Rakerwil dan Rakorwil. Komunikasi politik dalam keterbukaan ideologi DPW PKS Jawa Barat terjadi melalui pola komunikasi organisasi. Hal ini dikarenakan aktivitas komunikasi dilakukan oleh organisasi politik/partai politik. Menurut Pace \& Faules (dalam Mulyana, 2006: 31-33), komunikasi organisasi merupakan perilaku pengorganisasian yang terjadi dan bagaimana mereka terlibat dalam proses itu bertransaksi dan memberi makna atas apa yang terjadi. Selain itu komunikasi politik merupakan suatu proses pengoperan lambang-lambang atau simbolsimbol komunikasi yang berisi pesan-pesan politik dari seseorang atau kelompok kepada orang lain dengan tujuan untuk membuka wawasan atau cara berpikir, serta memengaruhi sikap dan tingkah laku khalayak yang menjadi target politik (Cangara, 2014: 30).

Komunikasi politik dalam keterbukaan ideologi DPW PKS Jawa Barat terjadi dalam lingkup organisasi politik, di mana komunikasi tersebut mempertukarkan pesan-pesan politik baik pesan verbal maupun nonverbal. Komunikasi terjadi pada kegiatan-kegiatan kepartaian yang dilaksanakan oleh DPW PKS Jawa Barat seperti; Musyawarah wilayah, Rapat kerja wilayah dan Rapat koordinasi wilayah. Dalam komunikasi politik melalui kegiatan tersebut, keterbukaan ideologi disampaikan DPW PKS Jawa Barat melalui pidato, serta arahan. Pada komunikasi politik melalui beberapa kegiatan tersebut, keterbukaan ideologi merupakan salah satu strategi partai 
untuk memperoleh konstituen yang lebih luas serta meningkatkan konsolidasi di tingkat intenal dan eksternal partai, serta terciptanya citra partai yang inklusif, partisipasi politik serta rekrutmen politik.

Komunikasi politik dalam keterbukaan ideologi menggunakan pola komunikasi ke bawah (downward communication). Menurut Lewis (1987) dalam Muhammad (2001: 8), komunikasi ke bawah adalah untuk menyampaikan tujuan, untuk merubah sikap, membentuk pendapat, mengurangi ketakutan dan kecurigaan yang timbul karena salah informasi, mencegah kesalah pahaman karena kekurangan informasi dan mempersiapkan anggota organisasi untuk menyesuaikan diri dengan perubahan. Pesan tersebut biasanya berhubungan dengan pengarahan, tujuan, disiplin, perintah, pertanyaan dan kebijakan umum.

Dewan Pimpinan Wilayah (DPW) PKS Jawa Barat melakukan komunikasi politik dalam keterbukaan ideologi melalui kegiatan Muswil, Rakerwil dan Rakorwil. Komunikasi melalui kegiatan tersebut dilakukan oleh berberapa komunikator politik dari internal serta eksternal PKS, dengan komunikan juga dari internal dan eksteral. Komunikator memberikan pesan dalam bentuk pidato dan arahan. Hal ini dilakukan dengan pemahaman menganai keterbukaan ideologi melalui pesanpesan politik yang disampaikan dan diusung oleh PKS. Kemudian secara simbolis DPW PKS Jawa Barat juga menunjukkan keterbukaan ideologi dalam bentuk simbol-simbol nonverbal seperti; undangan pada parti lain, ormas Islam $\mathrm{dsb}$, melalui pelestarian seni serta budaya daerah, serta kegiatan kemasyarakatan, sehingga akan terbangun citra partai yang inklusif dan berkidmad untuk rakyat.

Keterbukaan ideologi yang diusung oleh DPW PKS Jawa Barat disampaikan dalam komunikasiverbaldilakukan dengan komunikasi ke bawah, dengan proses komunikasi satu arah (one way communication) di mana komunikasi hanya berlangsung pada satu pihak yaitu komunikator internal maupun eksternal PKS, dilakukan secara tatap muka (face to face) menyampaikan pidato serta arahan kemudian komunikan internal serta eksternal partai mendengarkan, tanpa memberikan respon/ umpan balik dengan intensitas komunikasi tinggi. Kondisi tersebut hampir terjadi pada semua kegiatan seperti misalnya saat pidato atau arahan disampiakan, baik di dalam ruangan maupun di luar ruangan pada acara Muswil, Rakerwil dan Rakorwil. Selain dengan proses komunikasi satu arah, pada komunikasi politik dalam keterbukaan ideologi DPW PKS Jawa Barat juga menggunakan proses komunikasi dua arah (two way communication). Namun komunikasi dua arah hanya terjadi dengan intensitas rendah dan hanya terjadi saat Rakorwil yaitu saat Syaikhu menanyakan kesiapan kader yang menjadi peserta Rakorwil untuk membangun Jawa Barat lebih baik bersama semua elemen bangsa.

Keterbukaan ideologi merupakan bagian dari upaya mendapatkan kekuasaan serta mempertahankannya. Demokrasi yang sudah terinstitusionalisasi secara baik, ideologi partai akan mengarah ke tengah dan membuat sekat ideologi antar partai semakin tidak jelas. Dengan kata lain partai-partai politik akan semakin pragmatis dalam upaya mendapatkan kekuasaan (Surbakti, 2010: 128). Begitu juga yang dilakukan PKS, dari beberapa komunikasi politik yang dilakukan DPW PKS Jawa Barat, disampaikan mengenai target-terget perolehan suara ke depan, strategi-strategi partai yang lebih berorientasi pada market/pasar, serta tujuan politik yang jelas yaitu mencapai kekuasaan, memiliki posisi dan jabatan dalam pemerintahan.

Selain itu, komunikasi politik dalam hal keterbukaan ideologi yang dilakukan DPW PKS Jawa Barat terjadi tidak secara alami. Berbagai kegiatan komunikasi yang dilakukan merupakan bagian dari strategi politik untuk membangun citra partai yang inklusif dan menghilangkan citra partai yang eksklusif. Citra tersebut tentu dibangun salah satunya melalui kegiatan-kegiatan yang dilakukan.

Pembahasan pada beberapa kegiatan tersebut sama-sama menekankan pada tujuan partai, visi, misi yang ingin dicapai. Komunikasi dikemas dalam bentuk komunikasi politik berupa pidato dan arahan. Menurut Arifin dalam Hikmat (2011: 37-38), bentuk-bentuk komunikasi politik yang dilakukan komunikator dalam infrastruktur politik untuk mencapai tujuan politik diantaranya adalah retorika, propaganda, serta public relations. Komunikasi politik yang dilakukan DPW PKS Jawa Barat merupakan bentuk dari retorika, propaganda dan public relations. 
Hal tersebut sejalan dengan Teori interaksi simbolik yang dinyatakan oleh Herbert Mead (dalam Syam, 2012: 48) bahwa hubungan antara simbol dan interaksi, memahami bagaimana manusia bersama dengan manusia lainnya menciptakan dunia simbolik dan bagaimana simbol tersebut membentuk perilaku manusia. Keadaan tersebut dapat dipahami bahwa keterbukaan ideologi yang dilakukan oleh DPW PKS Jawa Barat adalah objek yang bisa secara langsung ditelaah dan dianalisis melalui interaksi manusia dengan lingkungannya. Dalam hal ini interaksi melalui komunikasi politik.

Berdasarkan hasil observasi dan wawancara yang peneliti temui di lapangan, komunikasi politik yang dilakukan oleh DPW PKS Jawa Barat terdiri dari beberapa tahapan, yaitu tindakan, gerak isyarat, simbol-simbol signifikan, pikiran (mind), diri (self), dan masyarakat (society) (Mead dalam Ritzer, 2012: 603-623). Pikiran merupakan kemampuan individu membangkitkan di dalam dirinya bukan hanya respon tunggal dari orang lain tetapi respon komunitas secara keseluruhan. Pada konteks komunikasi politik dalam keterbukaan ideologi DPW PKS Jawa Barat, pikiran di sini diartikan bahwa penelitian ini berangkat dari satu asumsi keterbukaan ideologi itu sudah ada, dan itu diartikan bahwa kader/anggota PKS memiiki pikiran yang sama (intensi) bahwa mereka harus terbuka.

Selanjutnya, diri (self) muncul seiring dengan perkembangan melalui kegiatan dan hubungan sosial. Untuk melihat pikiran, individu melihat dari berbagai tindakan, baik tindakan verbal maupun tindakan nonverbal, yang juga merupakan bagian dari gerak isyarat (gestur). Dalam konteks penelitian ini, DPW PKS Jawa Barat melihat diri mereka melalui pesan-pesan verbal yang telah disampaikan, seperti: pesan untuk bekerjasama dengan semua elemen bangsa, dengan partai lain dan stakeholder di Jawa Barat, meningkatkan konsolidasi internal dan eksternal, menerima pluralitas, meningkatakan pelayanan, pemberdayaan dan pembelaan, penentuan target-target perolehan suara pada pemilu, moderatisme, serta objektivikasi nilai-nilai Islam. Sedangkan tindakan nonverbal DPW PKS Jawa Barat adalah undangan ke partai lain, ormas Islam, pertujukan musik Islam yang berpadu dengan alat musik kontemporer, pertujukan puisi dll.
Kemudian masyarakat, dalam hal ini masyarakat dilihat sebagai ideologi partai yang terbentuk, maksudnya adalah berdasarkan tindakan personal dari anggota/ kader PKS terkait keterbukaan ideologi, kemudian akan mengarah pada tindakan komunitas (bersama) seperti yang telah dijelaskan pada pemaparan sebelumnya mengenai tindakan-tindakan yang mengarah pada keterbukaan ideologi DPW PKS Jawa Barat.

Kemudian simbol-simbol signifikan, yang dimaksud dengan simbol signifikan disini adalah simbol-simbol yang mendukung keterbukaan ideologi itu sendiri. Simbol signifikan dilihat dari tindakan sosial yang mendukung keterbukaan ideologi DPW PKS Jawa Barat.

Sehingga komunikasi politik dalam keterbukaan ideologi DPW PKS Jawa Barat merupakan bentuk serta tindakan yang telah diatur dan merupakan bagian dari tujuan komunikasi politik, dengan mempertimbangkan ekaspektasi komunikan atau sasaran dalam komunikasi politik. Dalam konteks ini makna yang diciptakan berupa kekuatan PKS sebagai partai politik yang kini lebih moderat, toleransi, menerima pluralitas, mau bekerjasama dengan semua elemen bangsa, dan inklusif (terbuka).

Secara ringkas, komunikasi politik dalam keterbukaan ideologi DPW PKS Jawa Barat disajikan dalam Gambar 1.

Menurut Arifin dalam (Hikmat, 2011: 39-41) tujuan komunikasi politik adalah penyampaian pesan politik dalam sebuah sistem politik tertentu oleh komunikator politik kepada komunikan politik. Tujuan komunikasi politik yaitu meliputi: citra politik, pendapat umum, partisipasi politik, sosialiasasi politik, pendidikan politik dan rekrutmen politik. Dalam komunikasi politik "perilaku" atau "tindakan" sama dengan komunikasi yang memiliki kepentingan politik. Beberapa kegiatan yang dilakukan DPW PKS Jawa Barat dalam bahasa nonverbal di atas merupakan komunikasi politik yang mereka sampaikan melalui beberapa perilaku serta tindakan yang menyangkut kekuasaan, pengaruh, autoritas, konsensus dan kerjasama.

Tujuan utama dalam komunikasi politik adalah penyampaian pesan politik verbal maupun nonverbal. Kodisi ini juga terjadi pada komunikasi politik dalam keterbukaan ideologi DPW PKS Jawa Barat. Pesan-pesan verbal 


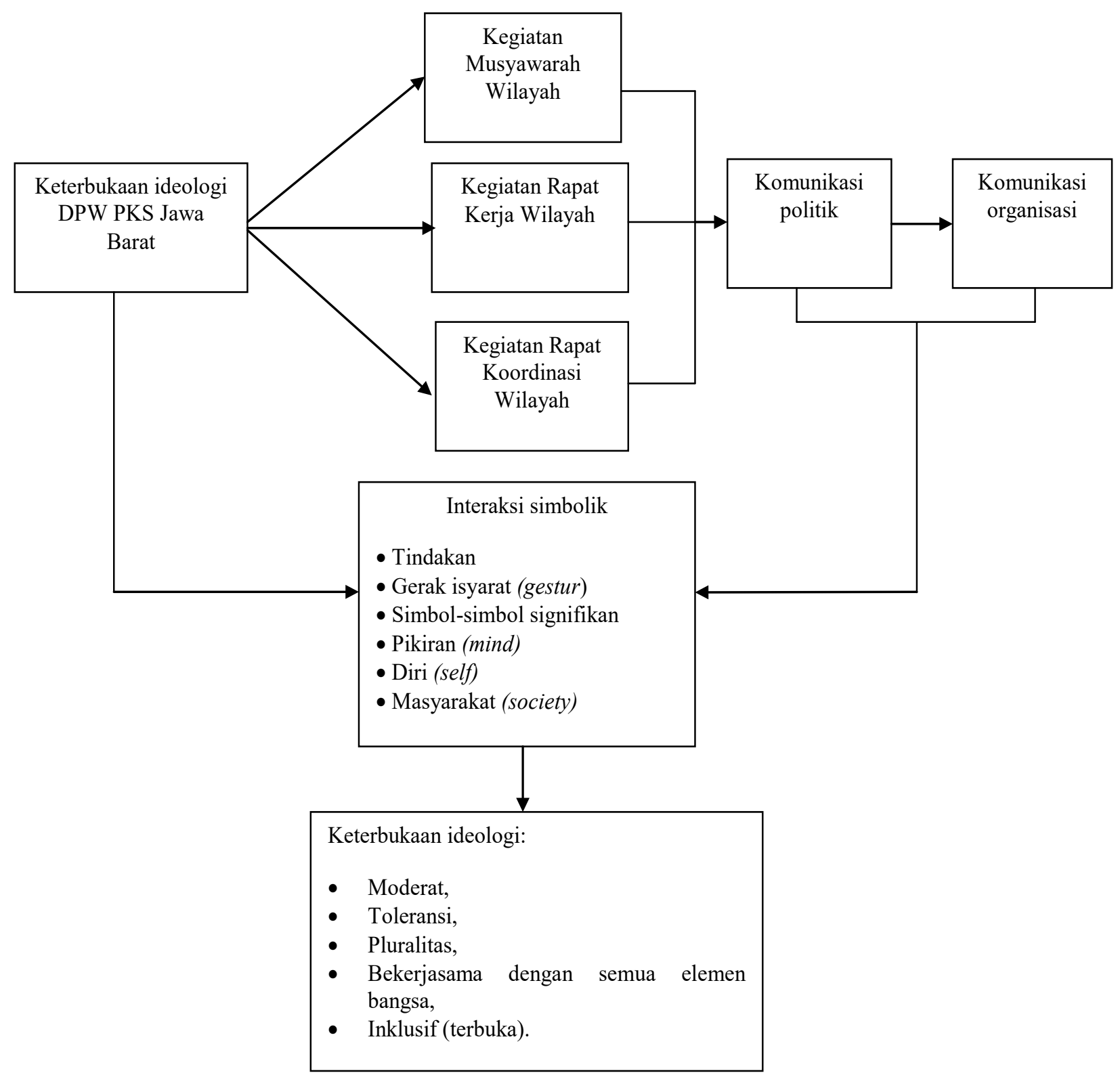

Sumber: Hasil Penelitian

\section{Gambar 1 Komunikasi politik dalam keterbukaan ideologi DPW PKS Jawa Barat}

disampaikan dalam bentuk pidato dan arahan pada kegiatan Muswil, Rakerwil dan Rakorwil. Kemudian pesan nonverbal disampaikan dalam bentuk tindakan serta perilaku politik pada kegiatan tersebut. Menurut Mulyana (2013: 92) simbol adalah sesuatu yang digunakan untuk menunjuk sesuatu lainnya berdasarkan kesepakan sekelompok orang. Simbol meliputi kata-kata (pesan verbal), perilaku nonverbal, dan objek yang disepakati bersama.

Hal tersebut sejalan dengan teori interaksi simbolik Herbert Mead (dalam Syam, 2012: 48) yang menekankan pada hubungan antara simbol dan interaksi, memahami bagaimana manusia bersama dengan manusia lainnya menciptakan dunia simbolik dan bagaimana nantinya simbol tersebut membentuk perilaku manusia. Keadaan tersebut dapat dipahami bahwa keterbukaan ideologi yang dilakukan oleh DPW PKS Jawa Barat adalah objek yang bisa secara langsung ditelaah dan dianalisis melalui interaksi manusia dengan lingkungannya. Dalam hal ini interaksi melalui komunikasi politik.

\section{SIMPULAN}

Komunikasi politik DPW PKS Jawa Barat dalam keterbukaan ideologi merupakan proses komunikasi dalam lingkup organisasi politik melalui kegiatan resmi kepartaian seperti Musyawarah Wilayah (Muswil), Rapat Kerja Wilayah (Rakerwil) dan Rapat Koordinasi 
Wilayah (Rakorwil). Komunikasi politik ini merupakan bagian dari bentuk penyampaian pesan keterbukaan ideologi DPW PKS Jawa Barat dari pimpinan kepada yang dipimpin. Selain itu, komunikasi merupakan bagian dari strategi politik untuk membangun citra partai yang inklusif dan menghilangkan citra partai yang eksklusif, menghilangkan stigma miring (stereotype) di masyarakat, membangun kerjasama dengan semua elemen bangsa, mendapat tempat di hati masyarakat, terciptanya kawasan baldatun toyyibatun warobbun ghofur, implememtasi slogan berkhimad untuk rakyat (pelayanan, pemberdayaan dan pembelaan) yang semuanya merupakan bagian dari tujuan dakwah secara umum dan tujuan politik secara khusus.

Berdasarkan kesimpulan dalam penelitian ini, maka peneliti memberikan saran-saran sebagai berikut: 1) Partai keadilan sejahtera (PKS) sebagai partai dakwah yang menjadikan ideologi Islam sebagai dasar perjungan partai diharapkan tetap menempatkan nilai-nilai Islam sebgai acuan dalam melakukan aktivitasaktivitas politiknya. 2) Masyarakat harus bisa lebih menerima perubahan-perubahan yang ada dalam partai politik, mengingat keterbukaan ideologi dapat menjadi terbaik yang bisa menampung pluralitas bangsa Indonesia melalui representasi pilar-pilar kebangsaan dan kenegaraan maupun sebagai bagian muslim moderat.

\section{DAFTAR PUSTAKA}

Alwasilah, A. C. (2003). Pokoknya kualitatif (dasar-dasar merancang dan melakukan penelitian kualitatif). Jakarta: Dunia Pustaka Jaya.

Arifin, A. (2011). Komunikasi politik filsafatparadigma-teori-tujuan-strategi dan komunikasi politik indonesia. Yogyakarta: Graha Ilmu.

Cangara, H. (2014). Komunikasi politik konsep, teori, dan strategi. Jakarta: Rajawali Pers.

Creswell, J. (1998). Qualitative inquiry and research design: choosing among five traditions. USA: Sage Publications.

Dik. (2008). Mukernas bali penegasan pks membuka diri. Diakses dari http://nasional. kompas.com/read/2008/02/01/19064654/ mukernas.bali.penegasan.pks.membuka.diri. tanggal 23 September 2015.

Hikmat, M. M. (2010). Komunikasi politik teori dan praktik. Bandung: Simbiosa Rekatama Media.

Kuswarno, E. (2008). Etnografi komunikasi. Bandung: Widya Padjadjaran.

Muhammad, A. (2008). Komunikasi organisasi. Jakarta: Bumi Aksara.

Mulyana, D. (2007). Metode penelitian komunikasi. Bandung: Remaja Rosdakarya.

Pace, R. W. \& Faules, D. P. (2006). Komunikasi organisasi strategi meningkatkan kinerja perusahaan. Diterjemahkan oleh: Deddy Mulyana. Bandung: Remaja Rosdakarya.

Permana, R. S. M. (2015). Makna tri tangtu di buana yang mengandung aspek komunikasi politik dalam fragmen carita parahyangan. Jurnal Kajian Komunikasi. Vol. 3.diakses dari, http://journal.unpad.ac.id/jkk/article/ view/7407/3409, tanggal 5 Mei 2016.

Purnanto, D. (2009). Etnografi Komunikasi dan Register [Online]. Diakses dari http:// dwipur sastra.staff.uns.ac.id/2009/06/03/ etnografi-komunikasi-dan-register, tanggal 25 Maret 2016.

Ritzer, G. (2012). Teori Sosiologi dari sosiologi klasik sampai perkembangan terakhir postmodern. Yogyakarta: Pustaka Pelajar.

Setya, T. R. 2009. Partai keadilan sejahtera. Diakses dari http://profil.merdeka.com/ indonesia/p/partai-keadilan-sejahtera/, tanggal 6 September 2015

Surbakti, R. (2010). Memahami ilmu politik. Jakarta: Grasindo

Susanto, E. H. (2013). Dinamika komunikasi politik dalam pemilihan umum. Jurnal Kajian Komunikasi, 1(1), 163-172.

Syam, N. W. (2012). Sosiologi sebagai akar ilmu komunikasi. Bandung: Remaja Rosdakarya Offset.

Taufik, H. A. (2009). Menyimak gerakan dakwah politik pks ekspansi gerakan tarbiyah pks kota bandung. Bandung: UNPAD Press

Wibowo, S. K. A., \& Mirawati, I. (2013). Realitas politik indonesia dalam kacamata pengguna twitter. Jurnal Kajian Komunikasi, $1 / 1,11-17$ 